\title{
地層内バイオメタン生産技術に関する過酸化水素を用いた石炭系材料の 有機物分解および内部構造の経時変化
}

\author{
荒牧 憲隆 ${ }^{1}$, 玉村 修司 ${ }^{1}$, 田中 翔 $^{2}$, 川㠃 ${ }^{3}$, 藤井 義明 $^{3}$, 金子勝比古 ${ }^{1}$
}

1 北海道科学技術総合振興センター・幌延地圈環境研究所

2 北海道大学大学院・工学院

3 北海道大学大学院 $\cdot$ 工学研究院

\begin{abstract}
概 要
本研究は, 地盤工学で発展した技術を資源エネルギー分野へと展開し, 地下圈バイオメタン生産技術確立 を念頭に置いている。地中のメタン生成の一つには微生物起源があり, 土や岩中の有機物から分解された 低分子量有機酸等を基質とし, 微生物の代謝生産物であるメタンが生成される。この流れを基本とした地 層内バイオメタン生産技術を確立するために，地中の有機物を低分子量有機酸に分解促進する必要がある。 この分解促進に過酸化水素を適用した。過酸化水素は, 鉄と用いることにより污染土壤中の有機物を分解 促進する効果を有する。本研究では, この土壤污染対策の技術原理を適用し, 地層内バイオメタン生産技 術に関わる石炭系材料の過酸化水素による有機物分解，その間隙構造の経時変化について検討を行った。 その結果, 低濃度過酸化水素で根源物質からメタン生成に必要な有機酸に分解促進されることが分かった。 また，材料の有機物分解時に間隙構造が変化し，微生物の生息空間を創出する可能性が示唆された。
\end{abstract}

キーワード : 褐炭, 過酸化水素, 有機物分解, 間隙構造, X 線 CT

\section{1.はじめに}

世界のエネルギー資源開発の現状は, 将来的なエネルギ 一需給のひっ迫が懸念される中で, 石油・天然ガスの開発 ニーズも容易に開発できる在来型資源にとどまらず, 開発 が困難な非在来型資源まで拡大しつつある1)。古くから利 用されてきた「通常の油・ガス田から開発される石油・天 然ガス」（=在来型資源）に対し, 代表的な非在来型資源 として, 石油系ではオイルサンドやシェールオイル, 天然 ガス系ではシェールガス，コールベッドメタン (CBM) などが挙げられる。また, メタンハイドレートも, 非在来 型の天然ガスの一種である。国内の非在来型資源開発に関 して, メタンハイドレートは我国周辺海域でも確認されて おり, その資源開発に, 近年, 地盤工学から積極的なアプ ローチがなされている2)。その他にも，石炭層が広く分布 し埋蔵量が多い北海道では, 石炭層に賦存するメタンを有 効に活用しようと種々の試みがなされている3)。石炭はク リートとマトリックスからなる二重孔隙システムを有し, それらにメタンガスが吸着していることから, そのガスを エネルギー資源として回収しようとする技術である。

この地下環境圈のメタンガスに着目すると, その生成に は熱分解起源によるものと微生物生成起源によるものな どがある。微生物起源のメタン生成プロセスには, メタン 生成微生物代謝のために基質が必要となる。通常, 地下環
境圈では, 地層中の化学的な作用や微生物によりメタン生 成微生物に必要な基質となる低分子量有機酸等が生成さ れる。この有機酸等をもとに, メタン生成微生物が代謝の 中でメタンを生成する4)。例えば，石炭は植物などの有機 物を起源とした堆積岩であり, メタン生成微生物が利用可 能な基質, 寸なわち難分解性ではあるが有機物を多く含有 している。これまで，地層中におけるメタン生成プロセス について, 幌延地圈環境研究所では北海道北部での堆積岩 や未活用の炭田をフィールドとして研究を進め, その一端 を明らかにしている56)。しかしながら，この微生物によっ て生成されるメタンを安定供給可能なエネルギ一資源と して考えた技術開発を行うに当たって, 低分子量有機酸生 成プロセスが時間的（反応速度）に課題となる。そこで, 本研究では, この低分子量有機酸生成プロセスのボトルネ ックを解消するために，過酸化水素の適用を試みた7)。

地盤工学における過酸化水素の活用事例は, 細粒土の粒 度試験における前処理の有機物の酸化分解 ${ }^{8}$, 地盤材料の $\mathrm{pH}$ 測定 ${ }^{9)}$, 酸性硫酸塩土壤の酸性度の判定 ${ }^{10)}$, 土壌污染対 策11)など, 実務, 研究および専門教育にと多く取り入れら れている。この中で, 土壌污染技術に着目すると, 過酸化 水素と鉄を用い, フェントン反応により生じる $\mathrm{OH}$ ラジカ ルの酸化力によって土畩中の污染有機物を短期に分解さ せる原位置での酸化分解工法が確立されている ${ }^{11)}$ 。エネル ギ一資源開発，特に，地層内で微生物によってメタン生成 


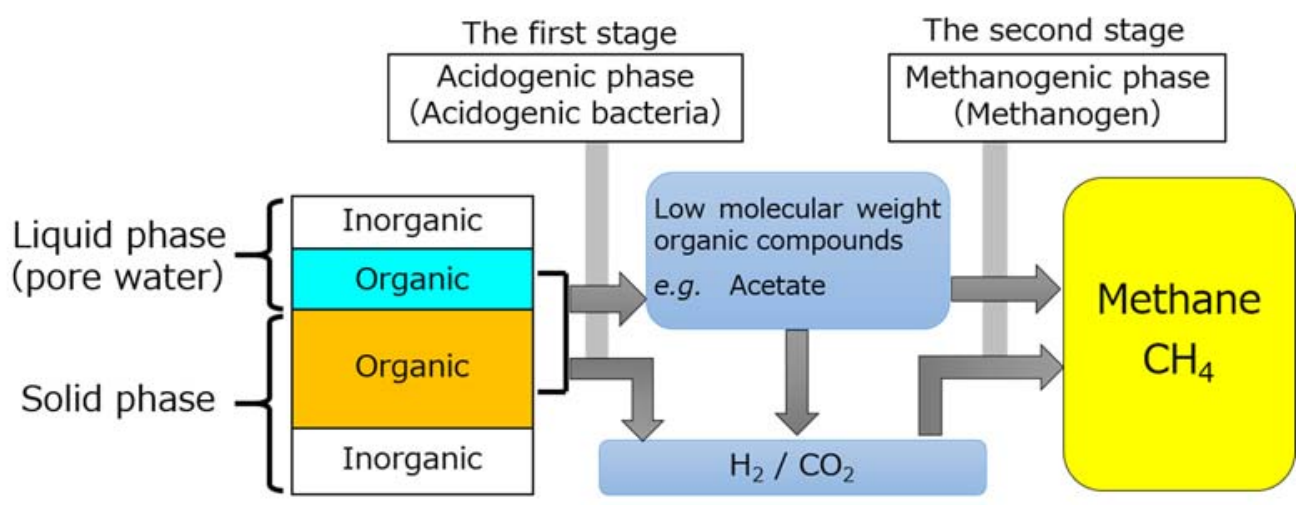

図 1 地下圈での微生物によるメタン生成の概念

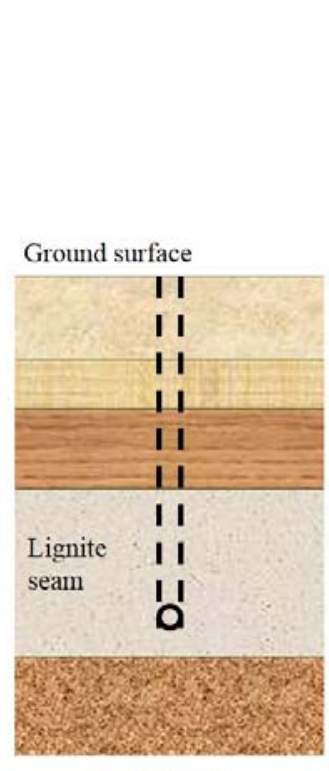

Drilling

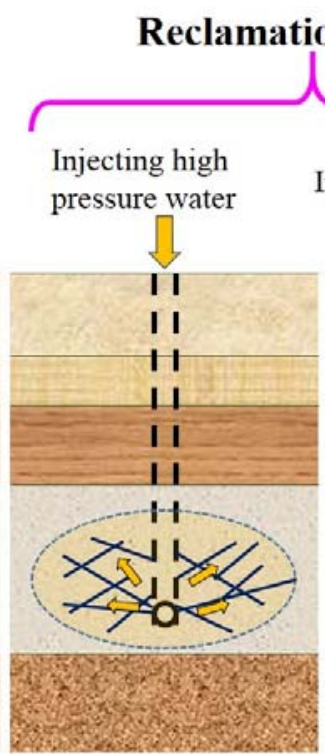

Hydrofracturing
Injecting $\mathrm{H}_{2} \mathrm{O}_{2}$ solution

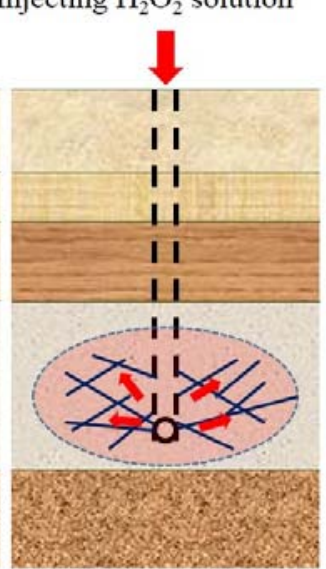

Assisted formation of methanogenic substrates

(a) Step 1

(c) Step 3

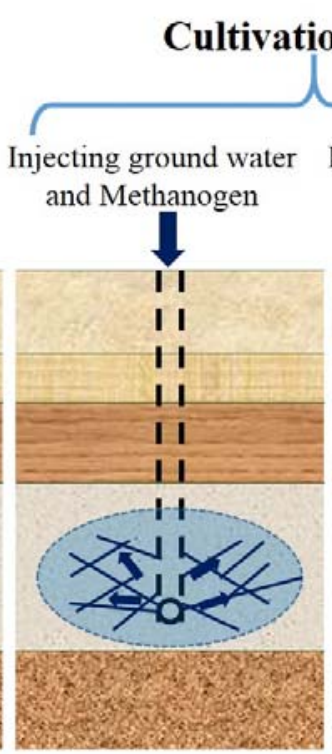

\section{Methanogen cultivation}

(d) Step 4
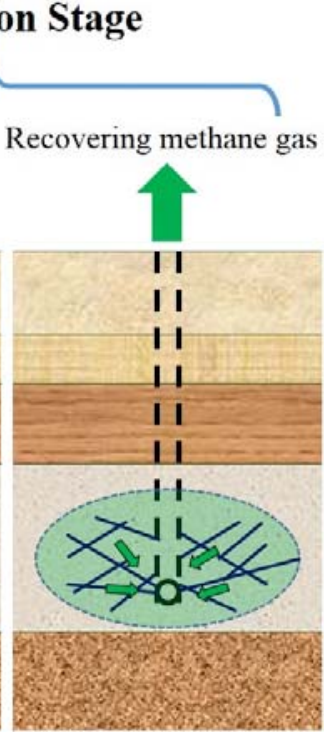

\section{Methane production}

(e) Step 5

図 2 バイオメタン鉱床造成/生産法（Subsurface Cultivation and Gasification）

を行う技術において, 根源物質となる岩層そのものを改良 する事例はほとんどない。

幌延地圈環境研究所では, エネルギー資源開発の問題に 対して, 地盤工学に関わる知見, 技術を有機的に結びつけ, 大深度地下圈でのバイオメタン鉱床造成/生産法

(Subsurface Cultivation and Gasification, 以後 SCG 法と称 す）の確立を目指している。特に, 前述のボトルネックで ある低分子量有機酸の生成過程において, 原位置酸化分解 法の適用を検討している。本研究では, 土壇污染対策であ る原位置酸化分解法の技術原理を適用した SCG 法による バイオメタン生成プロセスにおいて, 石炭層での実施を想 定し, 過酸化水素水に浸漬した石炭系材料の有機物分解プ ロセス, マイクロ X 線 CT 装置を活用したその間隙構造の 経時変化について基礎的な検討を行うことを目的として いる。
2. バイオメタン鉱床造成/生産法－SCG method (Subsurface Cultivation and Gasification)-

図 1 に, 地下圈における微生物起源のメタン生成プロセ スの原理を概念的に示した。嫌気状態（無酸素状態）で土 や岩に含まれる有機物からメタンへの分解（メタン発酵）

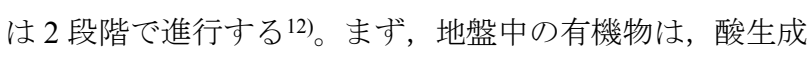
過程（液化過程）で化学的な作用や酸生成細菌群の作用に より, 低級脂肪酸や酶酸などの低分子有機化合物となる。 また, この低分子有機化合物である䣷酸以外の低級脂肪酸 などは, 水素生成細菌により水素之酢酸に変換される。そ して, これら生成物を利用し, 基質特異性の強いメタン生 成微生物によりメタンに分解される。生成されたメタンは, 地表面付近における有機質土が堆積する沖積低地や, 廃棄 物埋立地等でも, 地中溶存ガスとして顕在化している。著 者らが所属する幌延地圈環境研究所では, 北海道北部周辺 
での堆積岩からメタン生成に関わる微生物の培養に成功 している 5)。加えて, 北海道道北地方に堆積する新第三紀 層および新第四紀層（沖積層を含む）において，胚胎する メタンガスが微生物起源であることを明らかにし13), 同地 区での微生物起源のメタン生成ポテンシャルは高いこと が確認されている。しかしながら, メタンを安定供給可能 な資源として考えると, 低分子量有機酸生成プロセスが時 間的（反応速度）に課題となる（図 1 第 1 段階)。そこで, 本研究では, この低分子量有機酸生成プロセスのボトルネ ックを解消寸るために, 石炭の難分解性有機物分解に過酸 化水素を用いている7)。過酸化水素は前述のように土畩污 染対策技術として用いられる。污染土壌に過酸化水素と鉄 溶液を供給し, フェントン反応で生じる $\mathrm{OH}$ ラジカルの酸 化力により污染物質（VOC など）が酸化分解させる技術 であり, 原位置酸化分解工法（フェントン法）と呼ばれて いる。ここで, フェントン反応とは, 酸性の $\mathrm{pH}$ 域で過 酸化水素に鉄( II)化合物が触媒的に反応して, 酸化力の強 いヒドロキシルラジカル $(\cdot \mathrm{OH})$ を発生させる方法で, 反応 式は次のようになる。

$\mathrm{Fe}^{2+}+\mathrm{H}_{2} \mathrm{O}_{2} \rightarrow \mathrm{Fe}^{3+}+\mathrm{OH}^{-}+\cdot \mathrm{OH}$

$\mathrm{OH}$ ラジカルを発生させる種々の方法があるが, 本反応 は最も基本的な方法のひとつである。この $\mathrm{OH}$ ラジカル に酸化作用がある事が重要な点である。この原理を活用し， 根源岩中の難分解性有機物を酸化分解させ, メタン生成微 生物の基質を得ようとするものである。

著者らは, 地盤工学を含めたこれらの知見を有機的に結 びつけ，エネルギー資源問題の観点から，地下環境圏での SCG 法を提案している ${ }^{14)}$ 。その概念を図 2 に示す。SCG 法の大きな特徴として, 石炭層を例に挙げると, 炭鉱開発 を行わず, 地下で微生物の代謝によりメタンを生成し直接 ガスを資源採収可能な技術である。加えて, 在来型資源で ある石油層や天然ガス層（GL-1000〜 3000m 程度）の深度 に比べ, 浅深度 (北海道北部の石炭埋蔵深さ GL-600m 以 浅）での開発を想定している。また, 地中内に挿入する過 酸化水素は, 塩類を伴わず反応後は水となり, 地下圈にと っても環境負荷が小さい物質である。

その SCG 法によるメタンガス生産プロセスを概観する と, まず Reclamation Stage として, 対象地層までの鉛直ボ

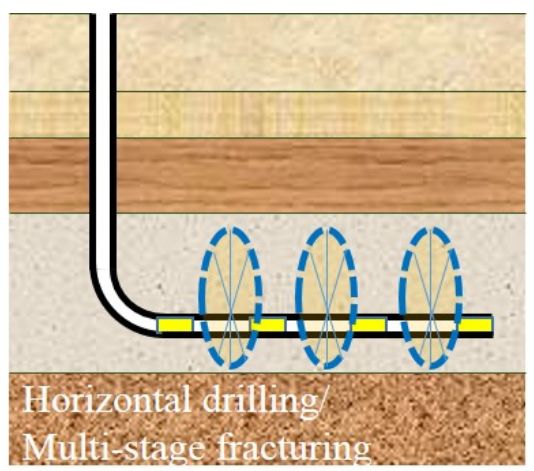

図 3 マルチステージフラクチャリングのイメージ
ーリング後, 地層傾斜に沿ってガス坑井を掘削する（図 2(a), 図 3)。その後, 高圧水を圧入し, 多段階の水圧破砕 により坑井から周辺にクラックを走らせる(図 2(b), 図 3)。 枝分かれしたクラックには砂状物質などを詰めて隙間を 保ち，そこに過酸化水素を注入することにより，還元的な 環境下にある地下を酸化的雰囲気下の環境にする。この後, 根源岩の難分解性有機物が低分子量有機酸へと酸化分解 され, メタン生成微生物に必要な基質を生成する（図 2(c)）。 次に, Cultivation Stage では, 還元剤の投入などによりメ タン生成微生物の生息可能な環境下へと地層改良し, ガス 坑井周辺のメタン生成微生物の活性化もしくは地上より メタン生成微生物を注入する（図 2(d)）。メタン生成微生 物が, 地層内で根源岩から分解された低分子量有機酸（酢 酸，ギ酸など）等を基質とし，メタンを生成する ${ }^{12)}$ 。SCG 法では，これを最終的にエネルギー資源として地下から直 接採収する（図 2(e)）ことが可能である。本研究では, 図 2(c)における石炭層の難分解性有機物分解過程を対象とし ている。

\section{3. 褐炭の過酸化水素水溶液浸漬実験}

\section{1 試料および実験方法}

本研究に使用した石炭系試料は, 北海道幌延町に位置す る北海道大学天塩演習林内の露頭から採取した褐炭であ る。褐炭の炭質 ${ }^{15)}$ は水分, 揮発分が多く, 石炭の中でも泥 炭に次いで低品質なため, 現在, 北海道北部周辺で操業中 の鉱山は無く, 火力発電所のエネルギー源等への利用はさ れていない。石炭の炭質, 鉱物組成, 化学組成等を考慮す ると, このような未利用資源は, バイオメタンの生産フィ 一ルドとして期待できる。本研究では, 図 4 に示したよう な $1 \mathrm{~cm}^{3}$ の立方体となるように供試体を作製し実験に用い た。過酸化水素を液相としたバッチ実験は, 室温 $25^{\circ} \mathrm{C}$ 一 定に空調管理された実験室において，1\%過酸化水素水溶 液を褐炭乾燥質量との固液比 L/S を 100 になるように調整 し, 嗍珪酸ガラス瓶に供試体を入れ, 静置した状態で行わ れた。実験では, 褐炭に含有する難分解性有機物の酸化

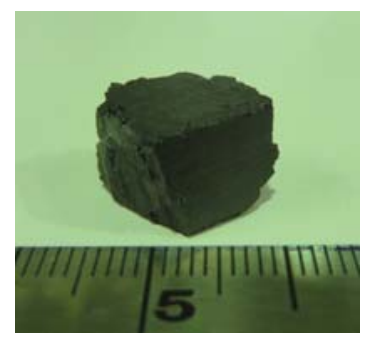

図 4 褐炭供試体の概観 表 1 実験条件

\begin{tabular}{lc}
\hline Concentration of hydrogen peroxide solution & $1 \%$ \\
Volume of hydrogen peroxide solution $\quad \mathrm{L}$ & $190 \mathrm{~mL}$ \\
Dry weight of lignite $\quad \mathrm{S}$ & $1.9 \mathrm{~g}$ \\
Solid-liquid ratio $\quad \mathrm{L} / \mathrm{S}$ & 100 \\
\hline
\end{tabular}




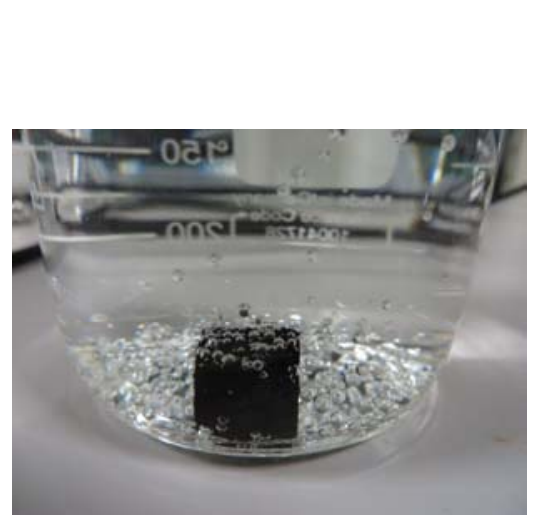

(a)浸漬 1 日目

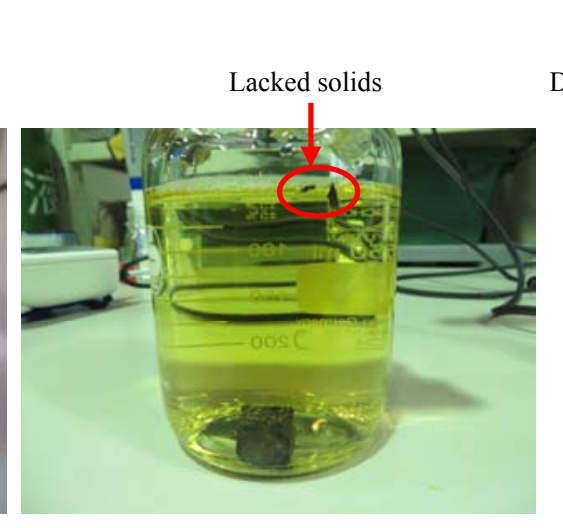

(b)浸漬 6 日目

図 5 実験概況

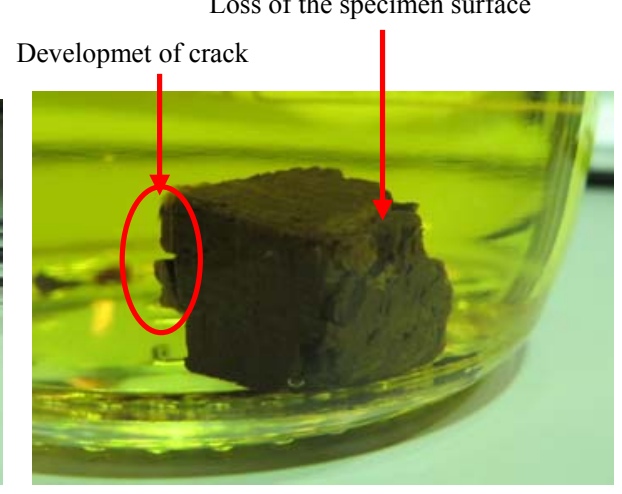

(c)浸漬 70 日目

分解過程において, 経時的に液相の化学分析を行っている。 分析項目として, $\mathrm{pH}$, 酸化還元電位 $\left(E_{\mathrm{h}}\right)$, 電気伝導率 $(\mathrm{EC})$, 溶存酸素量 $(\mathrm{DO})$ を液相から直接計測した。また, 液相 の過酸化水素濃度を同濃度計によって, 液相に溶存寸る全 有機炭素（TOC）濃度を燃焼法, 酢酸濃度, ギ酸濃度をイ オンクロマトグラフ法によって行っている。液相には, こ れら低分子量有機酸以外にも褐炭から酸化分解により他 の有機酸も溶出寸ると考えられるが, 本研究ではメタン生 成微生物の基質として代表的なものを選択し計測した。同 時に, 計測実施日には, デジタルカメラにより水溶液下の 供試体の外観を撮影し, 形状変化を観察している。表 1 に 実験条件をまとめた。実験は, 酸化還元電位 $E_{\mathrm{h}}$ より液相 が酸化的な環境から還元的に移行したと判断される 90 日 間行った。

\section{2 過酸化水素水溶液下の褐炭の形状変化}

図 5(a)〜(c)には過酸化水素水に浸漬した褐炭形状の経 時変化を示した。浸漬 1 日後, 褐炭表面に気泡が発生して いる様子が認められる（図 5(a)）。浸漬 6 日目（図 5(b)） において, 気泡の発生は続き供試体内部より発生した気泡 の影響により, 供試体は一部剥離し水面一浮き上がってい る。また, 水溶液は, 無色であった初期より淡い黄色の色 相に変化している。この気泡は, 過酸化水素と褐炭との反 応により発生した二酸化炭素と酸素が主成分であると推 察される。また, 水溶液の色相変化は, 腐植物質 (フミン 酸など）が褐炭の酸化分解により生成, 溶脱した結果によ り起こったと考えられる。図 5(c)に示した浸漬 70 日目に おいて, 気泡の発生量は少なくなり, 水溶液の色相は淡い 黄色から琥珀色へ変化したことが確認できる。褐炭供試体 には, 浸潤面で気泡の発生による表面の欠損や, クラック の発達による形状変化が認められた。図 6 は, 浸漬実験終 了後の乾燥した褐炭供試体である。側面に層状のクラック を生じているが，浸漬中には確認されなかったことから， 乾燥による供試体の収縮, 有機物分解による試料の脆弱化 による久損, 損失と考えられる。また, 供試体中心部は黒 色であり, 浸潤面となる周面は変色していることが認めら れる。黒色部分は未分解領域で, 変色部は過酸化水素によ

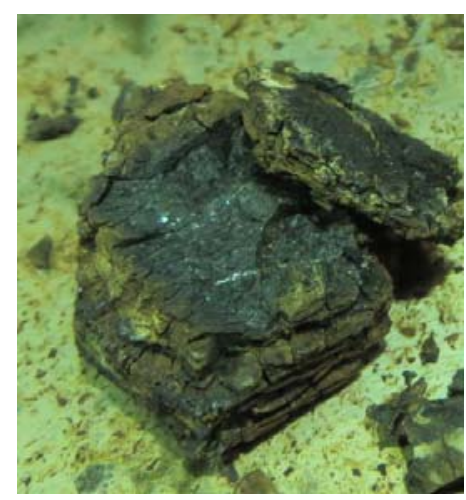

図 6 実験終了後の供試体

る褐炭の有機物分解領域であると考えられる。そのため周 面付近で変色領域が多くなっている。また, 供試体周辺に は細粒化した褐炭が存在し, 酸化分解により褐炭は脆弱化 したと考えられる。これらの結果より, 褐炭に含まれる難 分解性有機物の酸化分解過程において, 発生寸る気泡の影 響を受け, 褐炭の形状が経時的に变化する様子が認められ た。図6から, 供試体内部での変色も部分的に認められる ことから, 褐炭の空隙等の内部構造にも影響を及ぼしてい ると考えられる。

\section{3 褐炭の難分解性有機物酸化分解過程における液相 の化学分析}

褐炭有機物分解時の液相の化学的指標の経時变化につ いて検討を行った。図 7, 8 に $\mathrm{pH}$ および $E_{\mathrm{h}}$ の経時変化を 示した。図 7 より, pH は浸漬初期 1 週間で著しく低下し, 液相の酸性化が進んでいることが分かる。浸漬 28 日目以 降, $\mathrm{pH}$ は安定し 3 程度の酸性を示す。図 8 の $E_{\mathrm{h}}$ の経時変 化において, 浸漬初期に $E_{\mathrm{h}}$ は急激に増加し, 酸化的な環 境を示す。しかし, 浸漬 48 日以降, $E_{\mathrm{h}}$ は減少傾向へと転 じ，やや還元的な䨌囲気一と変化する。図 9 には, EC と 浸漬時間の関係を描いた。EC は, 浸漬 28 日目まで時間に 対し比例的な増加傾向を示寸が, その後 70 日目にピーク を迎えるまでは緩やかに增加し, 最終的には減少傾向を示 した。これは, 過酸化水素水溶液下に電解質イオンが溶脱 していることを意味する。また, 褐炭と過酸化水素との反 


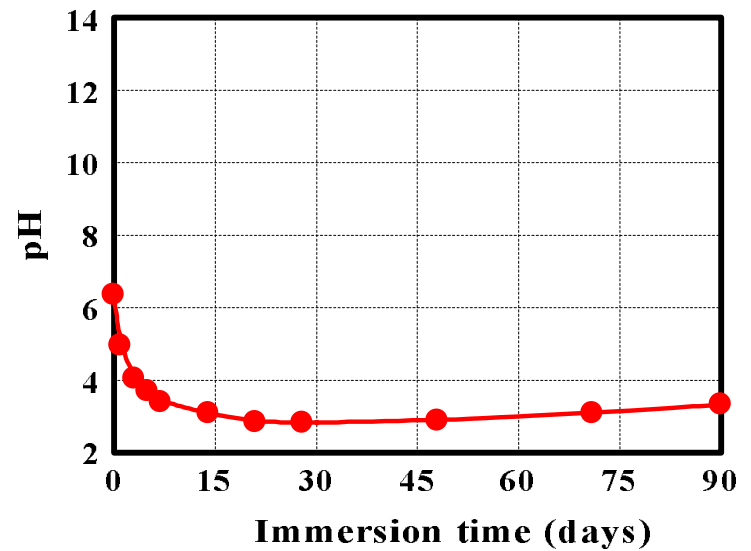

図 $7 \mathrm{pH}$ の経時変化

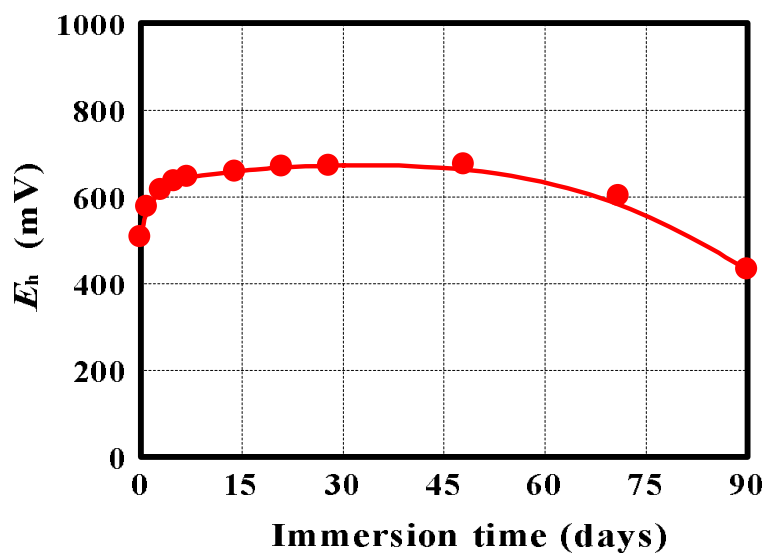

図 $8 \quad E_{\mathrm{h}}$ の経時変化

応により, 褐炭より分解された後述する電解質の有機酸が 増減していることを表していると考えられる。DOの経時 変化について, 図 10 に示した。図中， $25^{\circ} \mathrm{C}$ における水の 飽和溶存酸素量についても併記している。DO は，浸漬 1 日目にピーク值を示し，その後緩やかに減少傾向を示すが， 浸漬 90 日目で急激に減少している様子が窺える。浸漬 70 日までの水溶液の DO は $25^{\circ} \mathrm{C}$ 水の飽和溶存酸素量より も高い值を示しており, 液相が過飽和酸素状態であり, 3.2 で示した気泡の成分が, 酸素を含んでいることを示唆する ものである。しかし，浸漬 90 日で貧酸素水に近い状態ま で DO は減少し, この傾向は $E_{\mathrm{h}}$ の経時変化とも一致して いる。図 11 に, 液相の過酸化水素濃度の経時変化を示し た。液相の過酸化水素濃度は, 浸漬時間の増加に伴い, 緩 やかに減少していることが分かる。これらの結果から，褐 炭の有機物分解過程において, 液相は酸化的な環境となる ものの，次第に還元的な環境へと移行すると推察される。

次に, メタン生成微生物の基質となる有機酸生成につい て検討を行った。図 12 には, 液相中の全有機炭素 TOC の 経時変化について示している。この TOC は, 液相に溶存 していることから, 酢酸やギ酸に加え, 今回検討を行って いないが, 他の低分子量有機酸の前駆体を評価したものと 考えることができる。浸漬時間の増加に伴い, TOC は浸 漬 28 日目まで比例的に増加していることが分かる。その

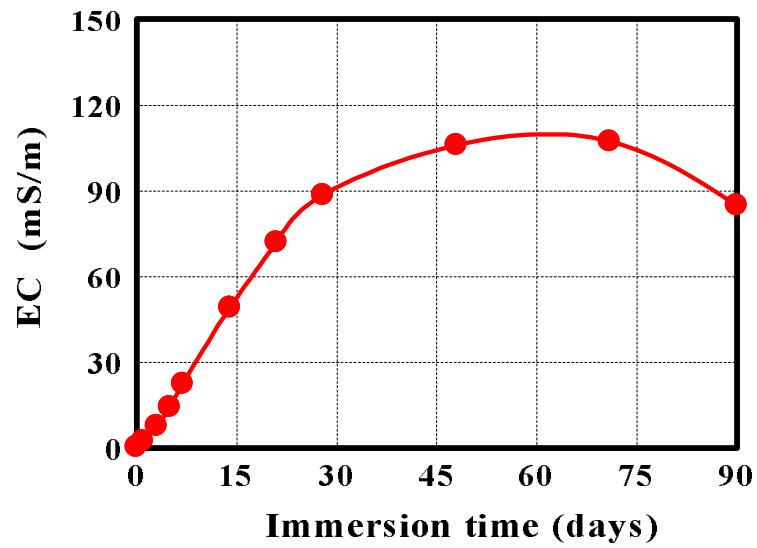

図 9 EC の経時変化

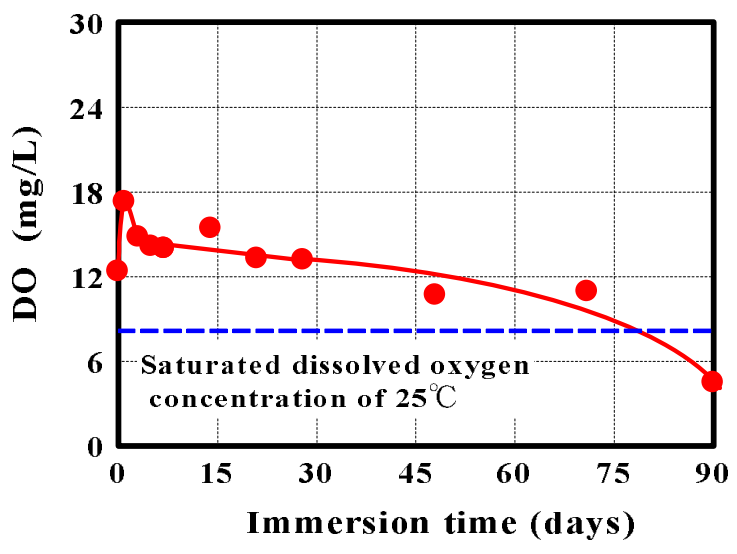

図 10 DO の経時変化

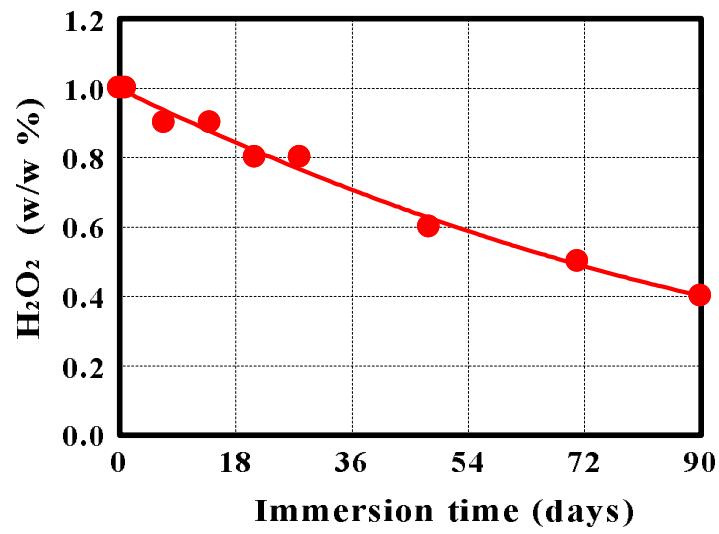

図 $11 \quad \mathrm{H}_{2} \mathrm{O}_{2}$ 濃度の経時変化

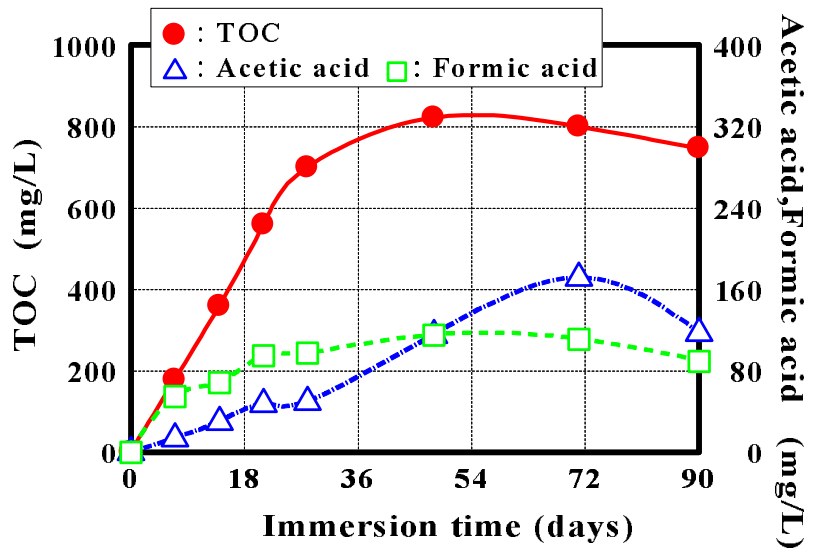

図 12 全有機炭素, 酢酸, ギ酸の濃度 


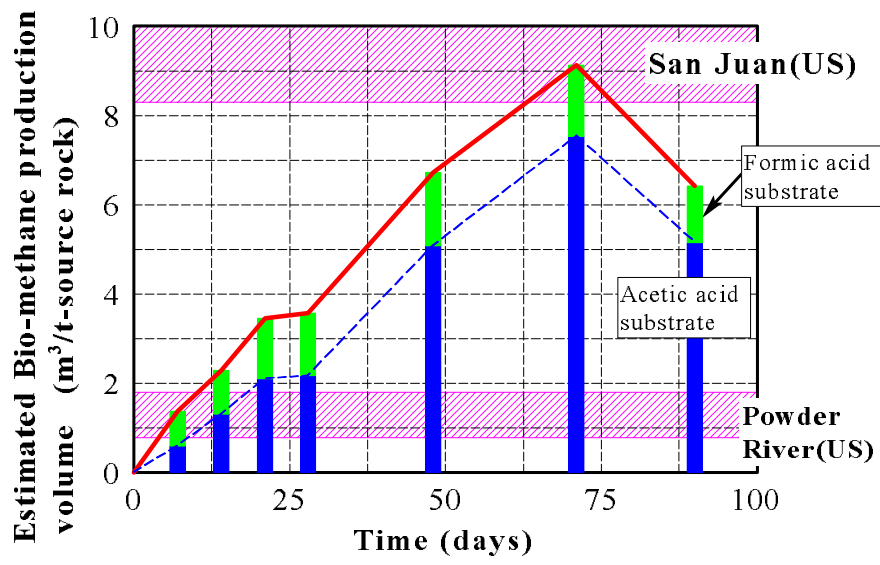

図 13 褐炭の微生物によるメタン生成ポテンシャル

後, TOC の増加割合は小さく, 浸漬 48 日目にピークを示 す。同図には, 酶酸, ギ酸の濃度も示した。TOC 同様, 時間経過に伴い両者の濃度は増加している。また, 酶酸濃 度は浸漬 70 日に, ギ酸濃度は 48 日目にそれぞれピークを 示すことが認められ, その後, それぞれの濃度は減少して いく。加えて, 褐炭の浸漬初期では, ギ酸濃度が高いが, 浸漬 48 日目以降，䣷酸濃度がギ酸より高くなっていく。 これらの有機酸の増加傾向は EC と類似していることから， $\mathrm{EC}$ の計測により, 有機酸濃度の増減の評価が可能である ことが示唆される結果 ${ }^{16)}$ である。また，1\%の低濃度過酸 化水素により, 褐炭の難分解性有機物分解を促進すること が認められた。

次に, これら有機酸を全て基質としてメタン生成微生物 が利用しメタンを生成すると仮定し, 酶酸 $\left(\mathrm{CH}_{3} \mathrm{COOH}\right)$ およびギ酸（HCOOH）から理論上のメタン生成量を次式 から導いた。

$\mathrm{CH}_{3} \mathrm{COOH} \rightarrow \mathrm{CH}_{4}+\mathrm{CO}_{2}$

$4 \mathrm{HCOOH} \rightarrow \mathrm{CH}_{4}+3 \mathrm{CO}_{2}+2 \mathrm{H}_{2} \mathrm{O}$

なお, メタン生成量の評価において, 本実験で得られた 酢酸およびギ酸の濃度をモル濃度（mol/L）に換算した上 でメタンを理想気体とし, その状態方程式より求めている。 図 13 には, 褐炭 $1 \mathrm{t}$ あたりのメタン生成量と時間の関係を 描いた。ここで，示した時間は，前述した分析計測時の時 間である。図中，アメリカの San Juan 炭鉱（ガス包蔵量 $8.5 \sim 17.0 \mathrm{~m}^{3} / \mathrm{t}$ ) ならび Powder River 炭鉱（ガス包蔵量 0.8 $\sim 1.9 \mathrm{~m}^{3} / \mathrm{t}$ ) での石炭 $1 \mathrm{t}$ あたりのメタン包蔵量も併記した ${ }^{17}$ 。 これらは，コールベッドメタンであり，アメリカで代表的 な商業用炭層ガス鉱床として生産が行われている。図より, 想定されるメタン全生成量は, 時間経過と共に増加してい く傾向にある。また, 生成されるメタンの内, 酢酸由来が 支配的である。さらに，7 日で Powder River 炭鉱，70 日で San Juan 炭鉱並みのガス包蔵量に匹敵するメタンの生成 ポテンシャルを示す。つまり, 微生物によるメタン生成に おいて, 北海道北部の褐炭層は商業用炭層鉱床並夕のポテ ンシャルを有すると示唆される。加えて，90 日目には想 定メタン生成量は減少しており，このような傾向を加味し
た上で, 図 2 に示した SCG 法の工程において, モニタリ

ングを行い Reclamation stageから Cultivation stage への移行 時期の判断が重要になってくると考えられる。

これらのことから, 過酸化水素は, 低濃度で褐炭中の難 分解性有機物の分解からメタン生成プロセスに必要な低 分子量有機酸生成し, 地層中でその環境を整えることが可 能であると考えられる。

\section{4. マイクロフォーカス X 線 CT による有機物分解 時の褐炭内部構造}

3.2 で示したように，有機物分解時の褐炭に形状変化が あることが認められた。その影響は，内部にまで及ぼすと 考えられる。ここでは, 有機物分解時の褐炭の内部構造変 化について, マイクロフォーカス X 線 CT スキャナを用い て検討する。

\section{1 試料および実験方法}

実験に用いた褐炭は，3．と同じ地点で採取されたもの である。供試体となる約 $1 \mathrm{~cm}^{3}$ 試料は，浸潤面となる上部 を除き，側方および底面をシリコンで覆い，アクリル製の 容器に固定した（図 14 参照）。固定により，撮影ごとの X 線 CT 装置内での試料設置位置の誤差を小さくし, 同一方 向からの撮影が可能になるようにしている。このことによ り, 撮影時期（浸漬日数）の異なる CT 画像に対して, 断 面の同定が容易となる。浸漬実験の条件は，3. と同様で 固液比 $\mathrm{L} / \mathrm{S} 100$ とした。この容器を $3 \%$ の過酸化水素溶液に 全てが浸るようにビーカー内に設置している。所定の時間 においてこの容器を取り出し， CT 撮影を行った。浸漬期 間は，21 日である。

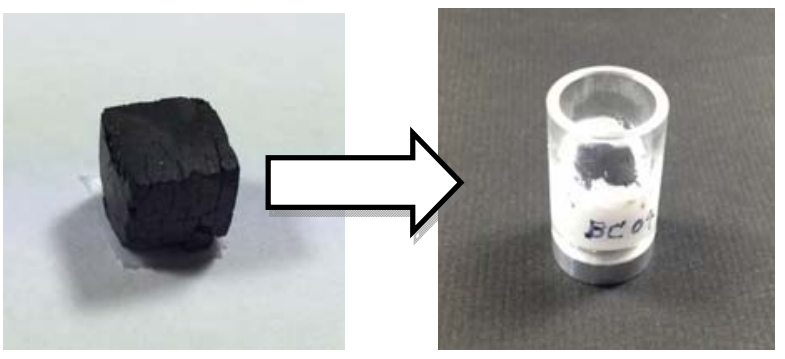

図 $14 \mathrm{X}$ 線 CT 撮影用供試体

有機物分解時の褐炭内部構造の観察には, マイクロフォ

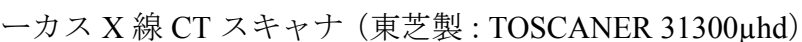
を用いた ${ }^{18) 19)}$ 。撮影は，コーンビームスキャンモードで行 われている。X線の管電圧と管電流は, 褐炭の密度を考慮 して，それぞれ $100 \mathrm{kV}$ と $62 \mu \mathrm{A}$ に設定した。断面画像の 画素数は $1024 \times 1024$ ピクセルとしたため, 空間分解能は $16 \times 16 \mu \mathrm{m}$ であり，スライス厚は $25 \mu \mathrm{m}$ である。

\section{2 観察結果および考察}

図 15 は, マイクロフォーカス X 線 CT スキャナで撮影 


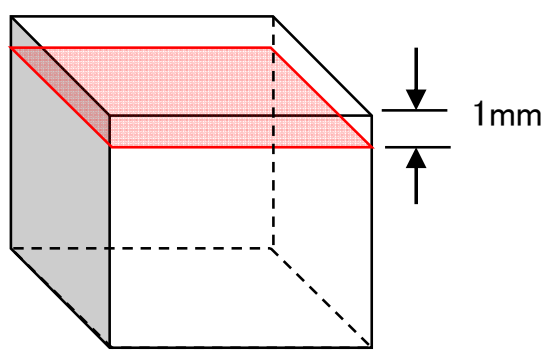

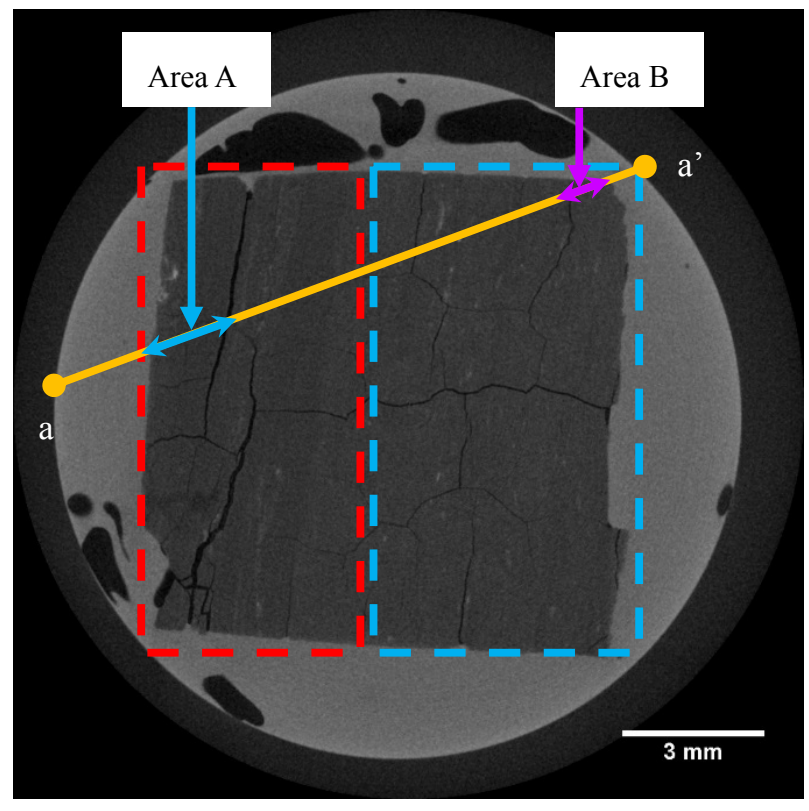

(a) 浸漬前

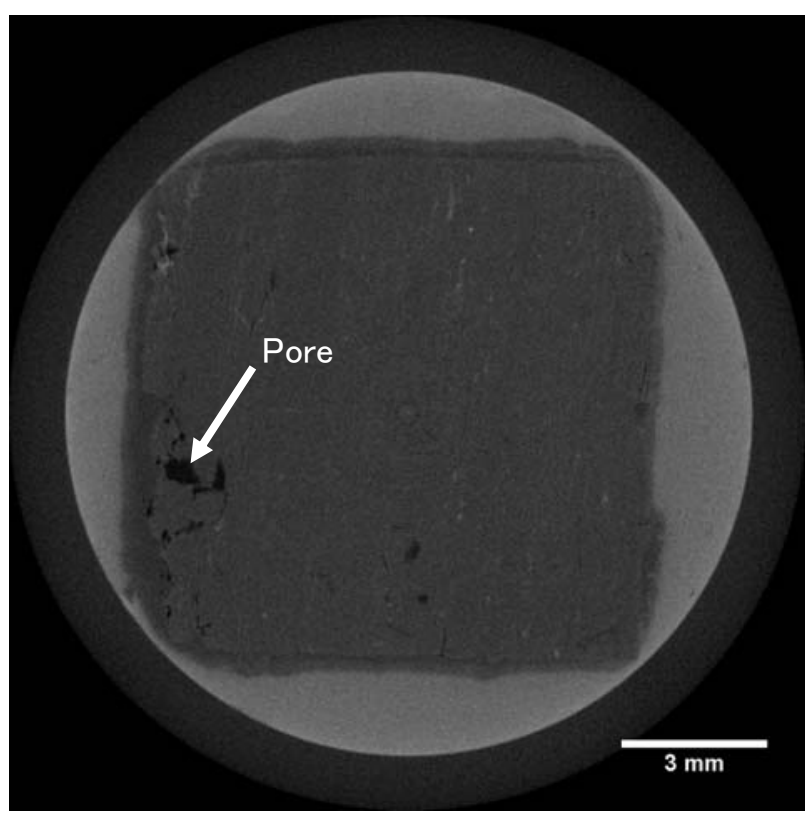

(c) 浸漬 14 日

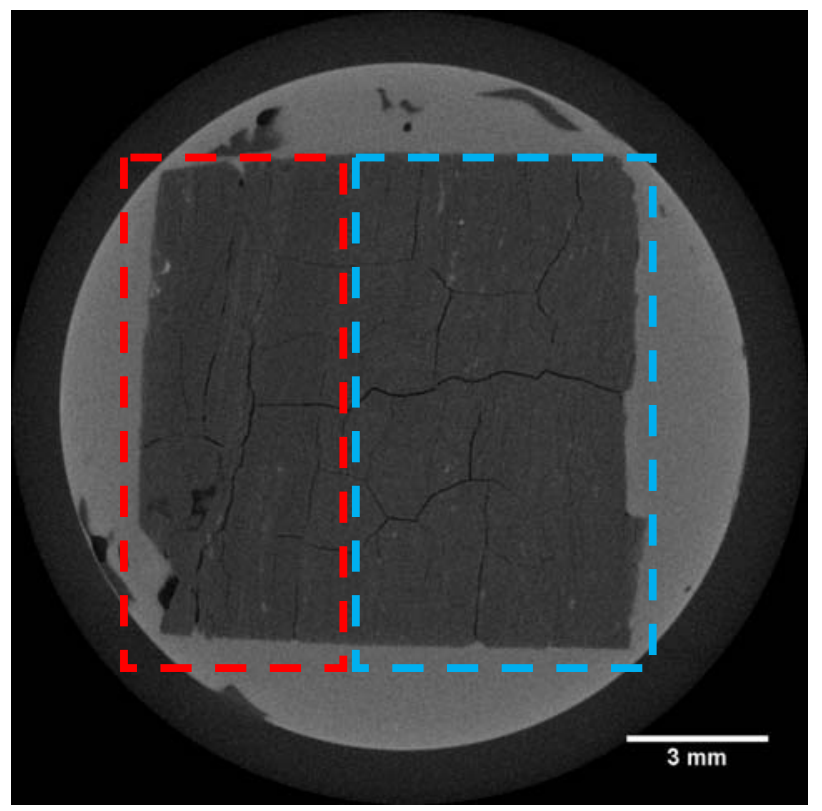

(b) 浸漬 1 日

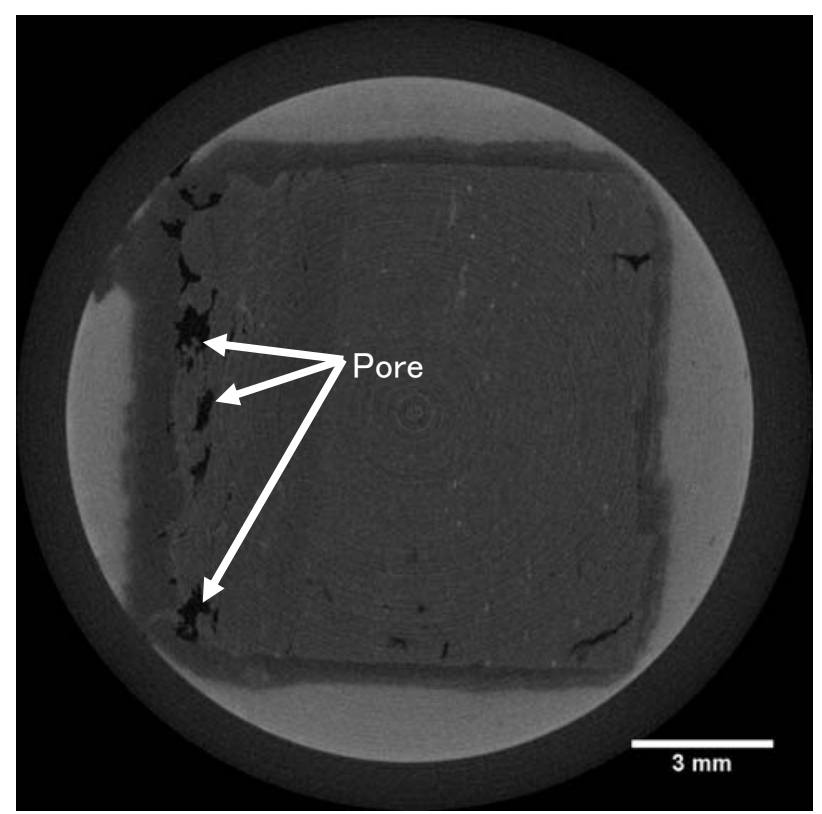

(d) 浸漬 21 日

図 15 褐炭上部より $1 \mathrm{~mm}$ 下方のスライス画像

された断面画像の例である。これらの画像は，上部浸潤面 より $1 \mathrm{~mm}$ 下方に位置する断面である。CT 画像は, 原子番 号や密度の違いが色の濃淡によって現れ, 密度の低い部分 は暗色, 密度の高い部分は白色で表される。したがって, 亀裂や間隙は, 褐炭の基質部に比べ暗い色で表される。褐 炭の場合, 鉱物組成を踏まえると, 白色の領域はパイライ
卜や珪酸質の比較的密度の高い鉱物であると考えられる 15)。褐炭周辺の白色部分は, シリコンである。なお，浸漬 日数の異なる試料断面の同定は, 断面中に存在する高密度 領域 (図中, 白色領域), 寸なわち過酸化水素と反応しな い無機物であると考えられる CT 值の分布状況から判断し た。同図(a)には, 浸漬前のスライス画像を示している。ス 
ライスの褐炭断面全体にクラックが存在していることが 認められる。同図(b)は, 浸漬 1 日目の褐炭のスライス画像 である。スライス左の赤枠破線で囲まれたクラックは閉じ ており, 青枠で囲まれたクラックは発達していることが認 められる。これは, 褐炭の吸水膨張の影響であると考えら れる。または，供試体がアクリルセルによって拘束されて いることから，褐炭の膨張量が拘束された可能性も考えら れる。同図(c)には, 浸漬 14 日目のスライス画像を示した。 同図(a), (b)に示されたクラックのほとんどが閉塞し認め られない。しかし，局所的に空隙が認められる。浸漬 21 日目になると, 空隙は, 供試体側面周辺に発達しているこ とが認められる（同図(d)参照）。褐炭を含む石炭は植物等 の有機物を起源とした堆積岩である。そのため, 過酸化水 素により褐炭が酸化分解され, 有機物の溶脱を伴う褐炭構 造の変化のために空隙化が起こったと考えられる。

X 線 CT スキャナで得られる断面画像は, 各 Voxel の CT 值を基準に構成される。Voxel とは断層画像を構成する最 小要素で, 断層画像は Voxel の集合体である。そして, CT
值は Voxel ごとに計算される19)。ここで, 図 16 にスライ スに対し図 15(a)に描いた a-a'ライン（全 12.8mm）上の 各 Voxel の CT 值についてまとめた。スライスの対象断面 は，図 15(a)，(b)および(d)である。同図の左右縦軸はアク リル容器とシリコンの境界付近（点 $\mathrm{a} ， \mathrm{a}$ ） であることを 表す。図 16(b)は，図 15(a)および図 16(a)に示した Area A を拡大して描いた。浸漬前の CT 值において, 点 $\mathrm{a}$ からの 距離 $2.0 \mathrm{~mm}$ 付近で $\mathrm{CT}$ 值に大きな差が認められる。これは, 褐炭とシリコンの境界であることを示す。この境界部分は, 浸漬日数の経過に伴い左方へ移動していることが分かる。 このことは, 褐炭が膨張していることを表している。また, 2.4 3.2mm の間で，浸漬初期に比心゙，浸漬 21 日の CT 值 は著しく減少し, 褐炭の有機物分解により空隙が形成され た様子がうかがえる。一方，同図(c)のArea B の点 a から の距離 $11.3 \mathrm{~mm}$ 付近において，浸漬前の $\mathrm{CT}$ 值が低く，ク ラックが存在している。浸漬 1 日目においても, クラック の存在は確認できる。しかし, 浸漬 21 日目の CT 值の分 布状況からクラックの存在は確認できない。むしろ, 浸漬

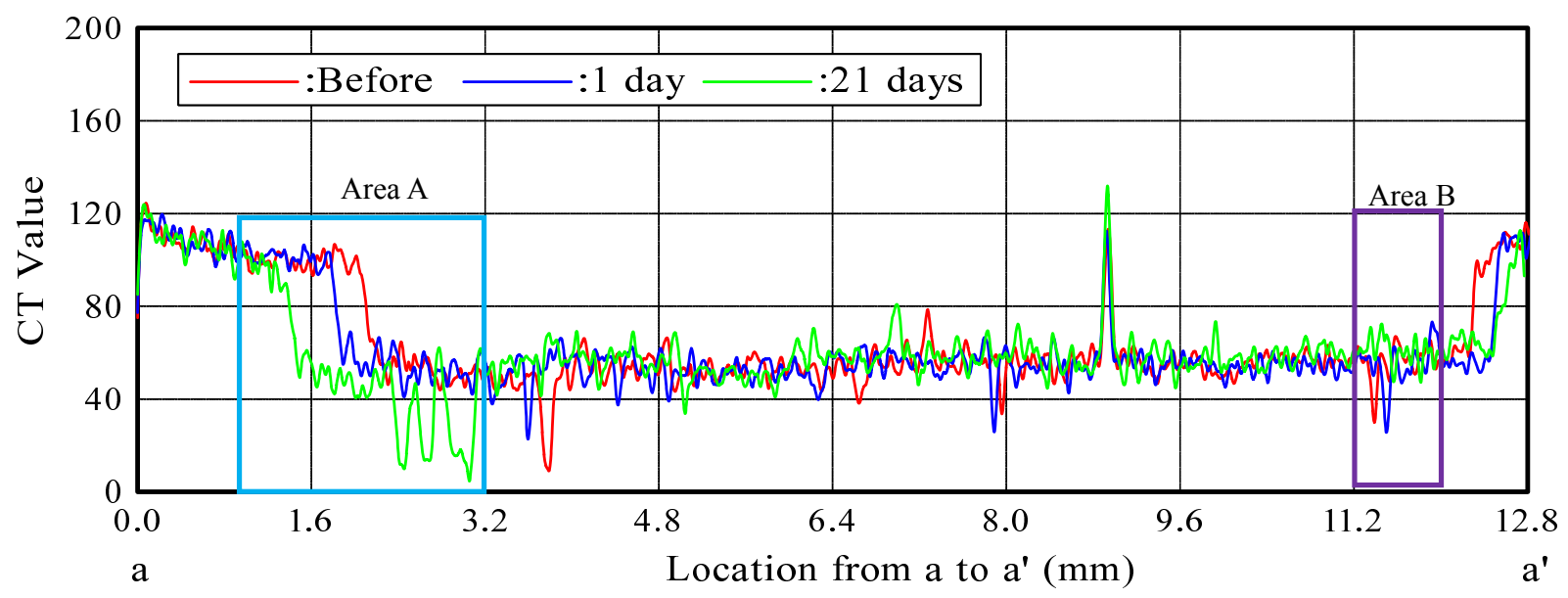

(a) a-a'ラインの CT 值の分布

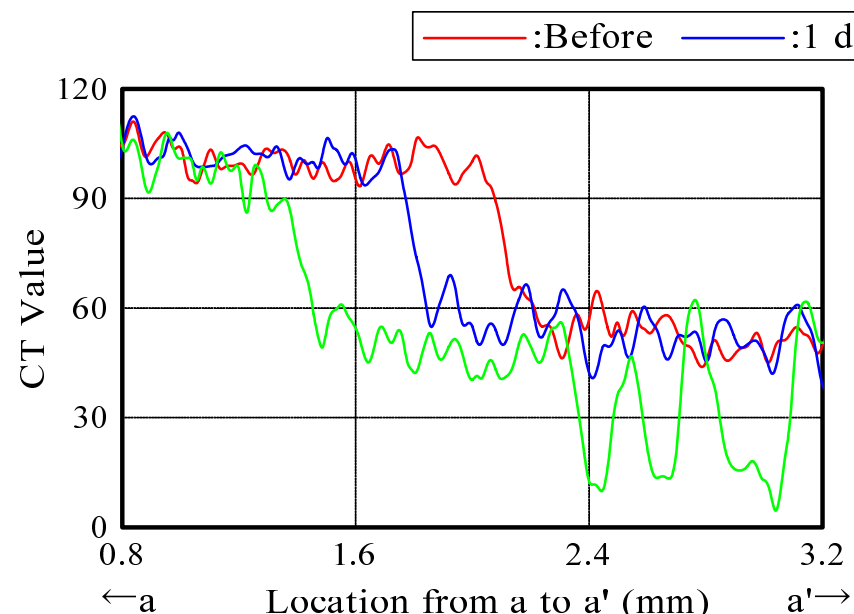

(b) Area A の CT 值分布 1 day $: 21$ days

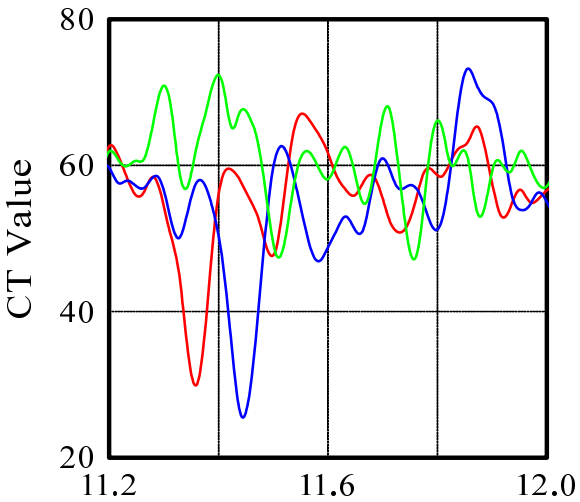

$\leftarrow$ a Location from a to $\mathrm{a}^{\prime}(\mathrm{mm}) \mathrm{a}^{\prime} \rightarrow$

(c) Area B $の \mathrm{CT}$ 值分布 


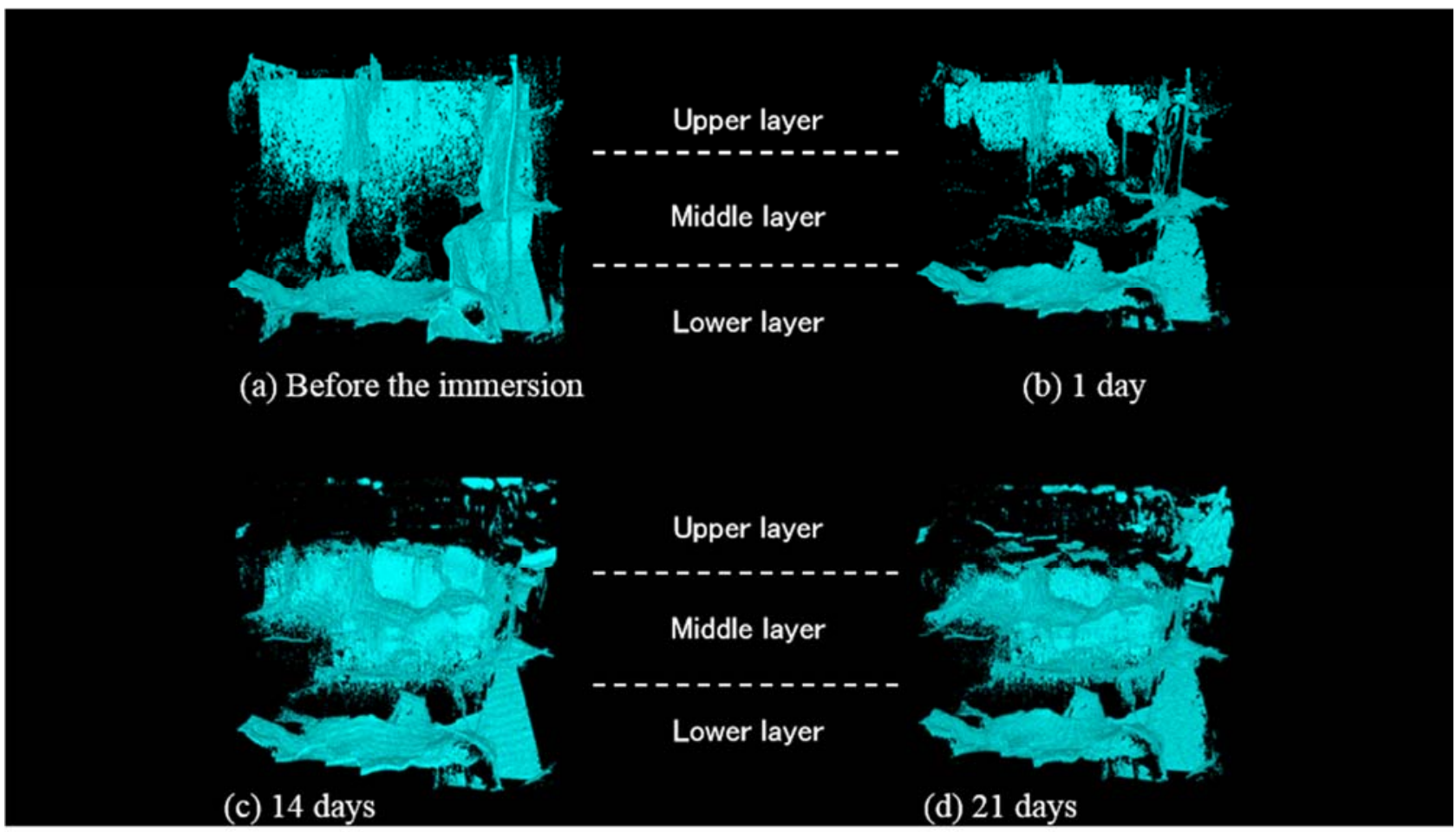

図 173 次元化された褐炭内部の間隙構造

前, 浸漬 1 日目よりも CT 值は増加していることから, ク ラックの閉塞によりこの領域では高密度になったと推察 される。

図 17 (a)〜 (d)は，全スライス画像をもとに画像処理 ${ }^{18) 19)}$ し, 所定の浸漬日数における褐炭中の空隙やクラックを抽 出し 3 次元化して示している。図中, 水色で描かれた部分 は, ある閾值以下 $\mathrm{CT}$ 值の領域であり, 約 $1 \mathrm{~cm}^{3}$ の褐炭供 試体（図 14 参照）内部の空隙やクラックを意味する。浸 漬前において, 試料表面から底面に至る巨視的なクラック があることが特徴的である。このクラックは, 供試体作製 時に進展したものと考えられる。この巨視的なクラックは, 供試体上部で, 浸漬日数の増加に伴い閉じていく傾向が認 められる。中央部では, 浸漬初期に大きな変化はないが, 浸漬 14 日目になると, クラックが水平方向に発達してい く様子が確認できる。過酸化水素の空隙への侵入により図 4 で示した気泡の影響，もしくは褐炭の吸水膨張により， クラックが進展していると考えられる。図 15 でも示した ように, 浸漬 14 日以降, 供試体上部において, 空隙と思 われる低密度領域が供試体周上部辺に沿って増えている。 この間隙構造の変化により, 微生物の生息空間を創出する 可能性が示唆されるものである。

これらのことから, 過酸化水素により酸化される褐炭は, 有機物の分解に伴い, クラックの進展, 形状, 変形特性に 大きく影響を受けることが認められた。

\section{5. まとめ}

本研究は, エネルギー資源開発の問題に対し, 地盤工学 で発展した技術原理を活用した地下圏での SCG 法の確立
を念頭に置いている。そのプロセスで必要となる根源岩か らの有機物分解促進に過酸化水素を用いた。その時の石炭 系材料における有機物分解時の化学的性質, 内部構造の経 時変化について検討を行った。以下に, 得られた知見を以 下に示す。

1) 褐炭と過酸化水素の反応において発生する気泡の影響 により，塊状の褐炭供試体は一部欠損した。

2）液相は, 褐炭の有機物分解時に酸化的雰囲気にあるこ とが認められた。また，溶存酸素量も多く，過飽和酸 素状態であった。

3) 過酸化水素水溶液は, 褐炭の低分子量有機酸の変換を 促進し，微生物によるメタン生成環境の一端を整える ことが認められた。また，微生物によるメタン生成量 は，商業用ガス鉱床に匹敵する量であることが想定さ れた。

4) マイクロフォーカス X 線 CT での観察結果から, 褐炭 の有機酸分解時において, 褐炭の体積変化, クラック の進展と閉塞, 空隙の発達等の褐炭の内部構造変化が 認められた。加えて, 微生物の生息空間を創出する可 能性が示唆された。

今後は, SCG 法におけるバイオメタン生産プロセスに おいて, 固液比, 過酸化水素濃度, 反応温度等の影響因子 に着目し, 原位置を想定した効率的な根源岩からの低分子 量有機酸生成について検討する予定である。

謝辞

幌延地圈環境研究所の清水了氏, 上野晃生氏には地下圏 のバイオメタンの知見に関し, 貴重な助言を頂いた。同研 究所，遠藤忠也氏，多田弘之氏，村元美雪氏には，試料の 
サンプリング，供試体整形に協力頂いた。三菱マテリアル 株式会社, 北海道大学北方生物圈フィールド科学センター には, 実験試料の提供やサンプリングや現地調查等の種々 のご教示を頂いた。付記して，深甚の謝意を表します。

\section{参 考 文 献}

1) 日本エネルギー学会編 : 非在来型天然ガスのすべてーエネルギ 一資源の新たな主役（コールベッドメタン・シェールガス・メ タンハイドレート）－，日本工業出版，270p，2014.

2）例えば, 兵動正幸, 中田幸男, 吉本憲正 : 深海底メタンハイドレ 一ト開発における地盤工学からのアプローチ, Journal of MMIJ, Vol.126 , No.10 11, pp.545-553, 2010.

3) 北海道 経済部 産業振興局 : 緊急雇用創出推進事業による「北 海道エネルギー問題懇談会」関連調查事業報告書, pp.1-18, 2010.

4) 川口慎介, 土岐知弘 : 海底下地殼内流体系のメタンの起源, 地 球化学, Vol.44, pp.137-154, 2010.

5) Shimizu S., Akiyama M., Naganuma T., Fujioka M., Nako M. and Ishijima Y.: Molecular characterization of microbial communities in deep coal seam groundwater of northern Japan, Geobiology 5, pp.423-433, 2007.

6) Ueno A., Shimizu S., Tamamura S., Naganuma T., Ohmi Y. and Kaneko K.: Structural Alteration of Humic Acids by Pseudomonas spp. from Deep Terrestrial Subsurface Diatomite Formations in Northernmost Japan. Geomicrobiology Journal 31, pp.654-663, 2014.

7) Miura K., Mae K., Okutsu H. and Minzuyani N.: New Oxidative Degradation Method for Producing Fatty Acids in High Yields and High Selectivity from Low Lank Coals, Energy \& Fuels, Vol.10, pp.1196-1201, 1996.

8）地盤工学会: 粒度試験, 地盤材料試験の方法と解説, pp.115-124, 2009.

9) 地盤工学会: 土懸濁液の $\mathrm{pH}$ 試験法, 地盤材料試験の方法と解説, pp.310-316, 2009
10）長谷川秀三，大津洋介，岩永安正，栗原昭司：酸性硫酸塩土壌 の過酸化水素による簡易 $\mathrm{pH}$ 測定法について, 日本緑化工学会誌, Vol.20, No.2, pp.116-122, 1994.

11) 平田健正，前川統一郎：土壌・地下水污染一原位置浄化技術の 開発と実用化一，シーエムシー出版，pp.197-203，2004.

12）例えば, 中村浩平, 鎌形洋一: メタン生成にかかわる共生微生物 系の研究と最新動向, Journal of Environmental Biotechnology, Vol.5, No.2, pp.81-89, 2006.

13）玉村修司，赤塚真依子，井川怜欧，越谷賢，清水了，上野晃生， 大味泰, 金子勝比古, 五十嵐敏文, 丸井敦尚 : 北海道北西部の 声問層〜沖積層に胚胎寸る溶存メタンの起源, 地球化学会誌, Vol.48, pp.39-50, 2014.

14) 荒牧憲隆，玉村修司，A.K.M. Badrul Alam，金子勝比古：北海道 北部における地層内バイオメタン生産技術に関する研究の現状 と展望一バイオメタン鉱床造成/生産法の提案一, Journal of MMIJ, Vol.131, No.6, pp.285-292, 2015.

15) Larry Thomas: Coal Geology, John Wiley \& Sons Ltd., 361p, 2011.

16）荒牧憲隆，玉村修司，清水了，上野晃生，金子勝比古：バイオ メタン生成プロセスに関わる低品位炭の過酸化水素浸漬実験に 関する検討, 資源・素材講演集(秋・熊本), Vol.1, No.2, A10-11, 2014.

17) Jenkins, C.D. and Boyer II C.M.: Coalbed- and Shale-Gas Reservoirs, Journal of Petroleum Technology, Vol.60, pp.92-99, 2008.

18) Fukuda D., Nara Y., Kobayashi Y., Maruyama M., Koketsu M., Hayashi D., Ogawa H., and Kaneko K.: Investigation of self-sealing in high-strength and ultra-low-permeability concrete in water using micro-focus X-ray CT, Cement and Concrete Research, Vol.42, pp.1494-1500, 2012.

19）山中裕史, 川﨑了, 加藤昌治, 椋木俊文, 金子勝比古 : マイク ロフォーカス X 線 CT を用いた二相構成材料の内部構造の相分 離に関する基礎的検討, 地盤工学ジャーナル, Vol.6, No.2, pp. 273-284, 2011.

(2015.3.19 受付) 


\title{
Aging behaviour of organic matter decomposition and microstructure of coal using hydrogen peroxide for bio-methane production in subsurface environment
}

\author{
Noritaka ARAMAKI ${ }^{1}$, Shuji TAMAMURA ${ }^{1}$, Sho TANAKA ${ }^{2}$, Satoru KAWASAKI ${ }^{3}$, \\ Yoshiaki FUJII $^{3}$ and Katsuhiko KANEKO ${ }^{1}$ \\ 1 Northern Advancement Center for Science and Technology, Horonobe Research Institute for the \\ Subsurface Environment \\ 2 Graduate School of Engineering, Hokkaido University \\ 3 Faculty of Engineering, Hokkaido University
}

\begin{abstract}
Microbial methanogenesis occurs in diverse subsurface environments. Biogenic methane is produced during the metabolism of methanogenic microorganisms. These microorganisms have the ability to produce methane using low-molecular-weight organic acids as substrates. These substrates are decomposed from hardly decomposable organic matter present in the source soil or rocks. An in situ clean-up method of ground contaminated with such compounds has been established, incorporating the Fenton reaction, utilising hydrogen peroxide and iron compounds. In this reaction, $\mathrm{OH}$ radicals are produced which can decompose toxic organic matter in the soil. With the aiming at developing of the production engineering of biogenic methane gas in the subsurface environments, we have proposed a new geotechnical method, known as Subsurface Cultivation and Gasification. This approach employs hydrogen peroxide to rapidly decompose organic matter. In this study, hydrogen peroxide solution immersion tests were performed on lignite in order to characterise the structural changes resulting from oxidation decomposition of hardly decomposable organic matter. It was found that the quantity of low-molecular-weight organic acids required for the microbial methanogenesis process increased with increasing immersion time. In addition, the interior structure of the lignite mass was significantly altered in the oxidation reaction, suggesting that the microorganism habitat space could be formed inside the source material itself.
\end{abstract}

Key words: lignite, hydrogen peroxide, organic matter decomposition, microstructure, micro-focus X-ray CT 